\title{
Structural Equation Modelling (SEM) on Teacher Competencies Test of Indonesian EFL Senior High School Teachers
}

\author{
Bita Dwi Rahmani1 ${ }^{*}$, Fitri Alyani ${ }^{2}$ \\ ${ }^{1}$ Department of English Education, Universitas Muhammadiyah Prof.Dr.Hamka \\ ${ }^{2}$ Department of Mathematics Education, Universitas Muhammadiyah Prof.Dr.Hamka
}

A R T I C L E I N F O

Article history:

Received 23 February

2020

Received in revised

Form 01 March 2020

Accepted 18 April 2020

Available online 30 May

2020

\section{Keywords}

Teacher Competencies

Test, Structural Equation

Model, Amos

\begin{abstract}
A B S T R A C T
The purpose of this paper is to investigate what factors influenced on Teacher competencies Test (Uji Kompetensi Guru/UKG) of Indonesian ESL Senior High School teacher's in West Java Indonesia. The data used in this study were derived from a teacher competencies test, and a questionnaire survey conducted among teachers who attended National Gathering of Senior High School English Teachers 2017 in Bandung, West Java. A total of 61 usable responses were received. The analysis was using Structural Equation Model (SEM) to see the correlations among variables also identify which predictors influenced most on Teacher Competencies Test. The result revealed that teacher competencies test was mostly influenced by education background ( $\beta=.27, p=0.028)$. It can be concluded that to increase the teacher's competencies can be done by giving a chance to teachers to continue their study.
\end{abstract}

\section{Introduction}

One of the activity which is important to do by the teacher is on evaluation stage. By undertaking the evaluation, teachers could both identify the student's achievement and also measure their own performance in the classroom. Teacher evaluations exist to ensure teacher quality and to promote professional development (DeMatthews, 2015). However, many authors doubt whether teacher evaluation procedures are succeed in reaching this professional development goal, (Frase, 2001). Sandholtz and Scribner (2006) stated that the professional development of teachers is often separated from the problems they experience in their classroom practice. However, teacher evaluation could and should offer the missing link between the reality of the classroom and actual teacher performance improvement. Therefore, teacher evaluation should cover the condition on the classroom but also the happening issue on the education field.

Indonesia, as one of develop country also requires kind of teacher evaluation to improve their teacher's quality through many teacher developments programs. One of the programs had been undergone by Ministry of Education in Indonesia is by running a teacher competencies test (UKG). The Teacher Competencies Test abbreviated as UKG (Ujian Kompetensi Guru) ) is a test to identify the teacher's competencies on professional and pedagogical in the teacher's content domain. However, according to Law Number 14 of 2005 concerning on Teachers and Lecturers, competencies means as a set of knowledge, skills, and behaviours that should be innated and mastered by the teacher in carrying out his/her professional duties. In addition, as stated in the Government Regulation (PP) Number 19 of 2005 concerning National Education Standards (SNP) article 28 paragraph 23, teacher competence is divided into four (4) aspects, namely: Pedagogic, personality, professional and social competencies. Based on the regulation implies that it is compulsory that teachers in Indonesia have sort of these competencies: namely pedagogical, personality, social, and professional, and all of these should be integrated and reflected in teacher performance. For EFL Senior High School Teacher in Indonesia, in particular, the first core competence is the content, the structure, the concept, and the thinking pattern of the subject matter. This competency is seen more operationally specified: having understanding of communicative competence covering linguistic, discourse, socio-linguistic, and strategic competence and mastering 
English, spoken as well as written, receptively and productively to develop students 'communicative competence. (Widiati \& Hayati, 2015). Therefore, UKG covered only two kinds of main competencies namely pedagogic and content knowledge of a subject matter mastered by EFL teacher in Indonesia.

As a matter of fact, the merit of conducting UKG is to provide a guidance and professional development services to teachers because the teaching profession will be qualified if there is continuous test and measurement of competence through UKG. In general, the purposes of the implementation of UKG are as follows:

1) To obtain information about the teacher competencies, especially pedagogical and professional competencies in accordance with established standards.

2) To obtain teacher competency maps that will be taken into consideration in determining the types of education and training that should be followed by teachers in the teacher professional training and development program in the form of continuous professional development activities.

3) To obtain UKG results that are part of teacher performance evaluation and will be the consideration for policy making in giving appreciation to the teacher (Zulfah, 2016).

In 2015, UKG was conducted to all teachers in all over Indonesia which covers 192 subject matter and or skills as a parameter in identifying the level of teacher's competence both in professional and pedagogic competence. Unfortunately, UKG in 2015 did not achieve standard expected target (Aisyah, I., Yuliasri, I., \& Warsono, W, 2018) as there were many factors influenced on it such as not only on educational background and teaching experience (Mustafa,M.N., 2013) , certified status (Kusumawardhani, 2017) , gender (Mustafa,M.N., 2013) but also on the involvement on professional organization and training (Grangeat, M \& Peter Gray,P., 2007) and their understanding on the pedagogical, content and curriculum knowledge (Mustafa,M.N., 2013) could affect the teacher competencies. Therefore, the further analysing is needed to investigate on which factors influenced most on teacher competencies test as well as identifying how big the contribution of each factor is. Thus, this research aims to design a best model on which factors influences on teacher competencies test. This research aims; 1) to identify which factors influenced direct and indirect mostly on teacher competencies test; 2) to predict the contribution of each variables toward the teacher competencies test; 3) and to examine the best model which fit on teacher competence test.

\section{Methods}

This research conducted quantitative method using Item Response Theory with Rasch model to analyse the items by software Conquest 4.0 (ACER, 2016). Structural equation modelling (SEM) was employed to analyse the best model for all variables through AMOS software. SEM is an extension of the general linear model (GLM) that enables a researcher to test a set of regression equations simultaneously. SEM software can test traditional models, but it also permits examination of more complex relationship and models, such as confirmatory factor analysis and time series analysis (University of Texas, 2012).

There were some analytical concepts employed too on SEM namely sample size, missing data and fit indices. Structural Equation Modelling (SEM) provides a very general and convenient framework for statistical analysis that includes several traditional multivariate procedures, In addition, SEM models are visualized by a graphical path diagram (Hox, J.J. , Bechger, T.M., 1999). Initially, the researchers made hypothesis in path diagram by using AMOS software. SEM has its roots in path analysis, so that, in this research, we would like to identify the influencing variables of Teacher Competencies Test (UKG). Each variable is also influenced by some factors. In SEM, we must specify a model before we start analysis and the model specification is usually guided by a combination of theory and empirical results from previous research. Once we have specified a model, we can estimate factor loadings and (co)variances. (Hox, J.J. , Bechger, T.M., 1999).

This study gathered a primer data analysis on teacher competencies test in 2015, teacher demography, and teacher self-assessment questionnaire that used to investigate the Indonesian ESL teachers knowledge on Pedagogical and Content (PCK). Factors comprising on 8 factors namely gender, school type, school location, education background, experience in teaching, training, professional organization, pedagogical content knowledge and curriculum change knowledge toward the teacher competencies test. On the data used for this analysis, Missing at Random (MAR) happened on several variables like Type of School, Teacher Competencies Test/UKG, Experience in Teaching and Training of Curriculum. The maximum likelihood was used in handling the missing value on this analysis. Fit indices for a single analysis are comparative fit index (CFI), Tucker-Lewis index((TLI, or non-normed fit index) and RMSEA. This study worked with categorical data which the TLI and CFI values, for categorical data, 
should be greater than or equal to 0.95 and the RMSEA, and the value should be less than or equal to 0.06 . Table 1 shows the variables in the initial model of teacher competencies test.

Table 1. Variables in the Initial Model of Teacher Competencies Test

\begin{tabular}{|c|c|c|}
\hline $\begin{array}{l}\text { Manifest } \\
\text { variables }\end{array}$ & Description & Coding \\
\hline GENDER & Teacher's Gender & $0=$ male, $1=$ female \\
\hline SCHOOL TYPE & Type of School & $\begin{array}{l}0=\text { Non-Government } \\
1=\text { Government }\end{array}$ \\
\hline SCHOOLLOCT & School Location & $\begin{array}{l}0=\text { West Region on Java Island } \\
1=\text { Middle East part of Java Island }\end{array}$ \\
\hline EDUCATION & $\begin{array}{l}\text { Teacher Educational } \\
\text { Background }\end{array}$ & $\begin{array}{l}0=\mathrm{S} 1 \\
1=\mathrm{S} 2\end{array}$ \\
\hline EXTEACHING & Experience in Teaching & Number of Years \\
\hline PROFORG & Professional Organization & $\begin{array}{l}0=\text { don't } \mathrm{tjoin} \\
1=\text { join }\end{array}$ \\
\hline TRAINING & Joining Training of Curriculum 2013 & $\begin{array}{l}0=\text { not yet } \\
1=\text { join }\end{array}$ \\
\hline CERTIFICATION & Certified & $\begin{array}{l}1=\text { Certified } \\
0=\text { not yet }\end{array}$ \\
\hline PCK1 & Pedagogical and Content Knowledge & Scores on Questionnaire \\
\hline CC2 & Curriculum Change & Scores on Questionnaire \\
\hline UKG & Teacher Competencies Test & Teacher scores \\
\hline
\end{tabular}

The participant of this study is 61 Indonesian English Teacher (ESL) mostly from West Java, some from East Java and Jakarta, Indonesia taken through random sampling. The data collection was held on National Gathering of Senior High School English Teachers 2017 in Bandung, West Java on July 6 2017. The population was about 200 teachers on the list.

\section{Result And Discussion}

The hypothesised teacher competencies test model consist of 9 variables and all variables are manifest (observed) variables. Figure 1 below presents the hypothesised of teacher competencies test derived from the theoretical framework. In the theoretical framework, it was proposed that variables consist of 9 variables. Those are gender, school type, school location, education, experience of teaching(exteach), professional organization(proforg), training of curriculum, certification, pedagogical and content knowledge(pck), curriculum change(cc), and teacher competencies test (UKG). As all variables on the model involve only observed variables, no further discussion on the measurement model.

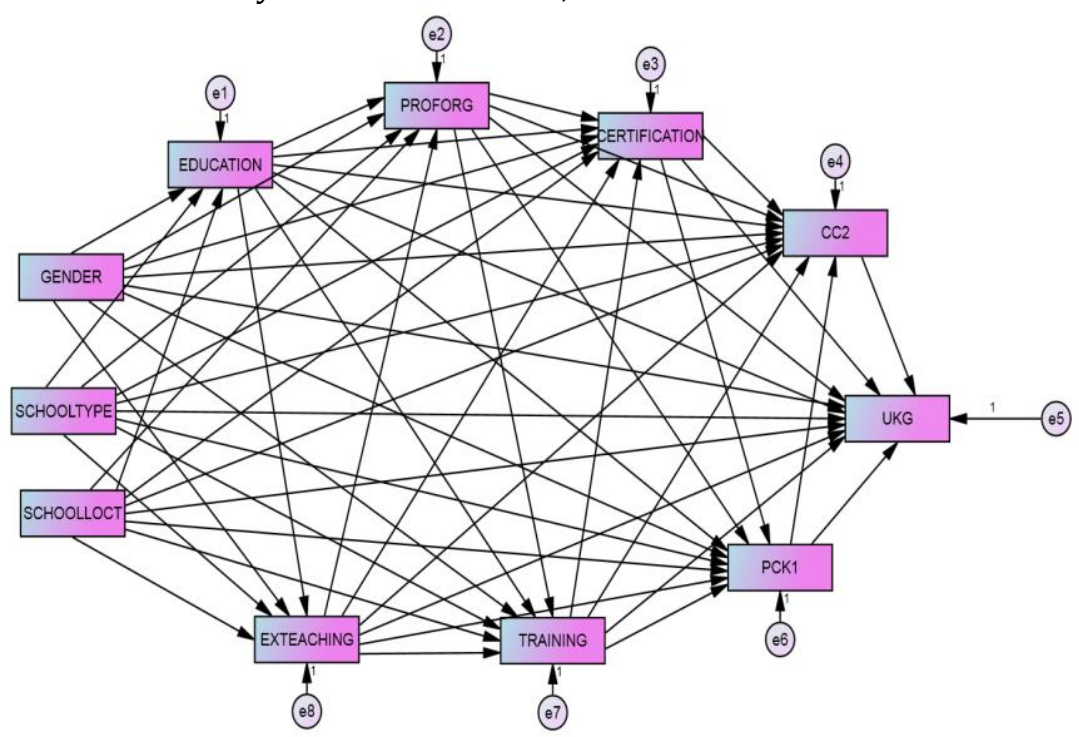

Figure 1. Initial Model of Teacher Competencies Test $(n=61)$

Three variables, gender, school type and school location are hypothesised as exogenous variables as they are not influenced by other variables. The remaining variables are viewed as endogenous as they 
may interact with one another. Variables in the process stage are viewed as endogenous because they mediate the effects or are influenced by variables.

Results of the Structural Model on Teacher Competencies Test (UKG)

The IBM SPSS Amos 22 structural model results are presented in the following figure below.

Table 2. Result on Teacher Competencies Test

\begin{tabular}{|c|c|c|c|c|c|c|c|c|}
\hline$\frac{\text { Variables }}{\text { Criterion }}$ & Predictor & UnstEst.(B) & $\begin{array}{l}\text { Direct Effect } \\
\text { S.E. }\end{array}$ & C.R. & $\mathrm{P}$ & StdEst. $(\beta)$ & $\begin{array}{l}\text { StdInd } \\
\text { effect } \\
\text { (ie) }\end{array}$ & $\begin{array}{l}\text { Total } \\
\text { effect } \\
(\beta+i e)\end{array}$ \\
\hline UKG & EDUCATION & 12.175 & 5.539 & 2.198 & 0.028 & 0.27 & - & 0.27 \\
\hline \multirow[t]{3}{*}{$\mathrm{CC} 2$} & GENDER & & & & & - & 0.06 & 0.06 \\
\hline & CERTIFICATION & & & & & - & 0.136 & 0.136 \\
\hline & PCK1 & & & & & 0.62 & - & 0.62 \\
\hline \multirow[t]{2}{*}{$\mathrm{CC} 2$} & GENDER & & & & & - & 0.248 & 0.248 \\
\hline & PCK1 & & & & & 0.62 & - & 0.62 \\
\hline TRAINING & PROFORG & -4.068 & 0.963 & -4.222 & $* * *$ & 0.48 & - & 0.48 \\
\hline
\end{tabular}

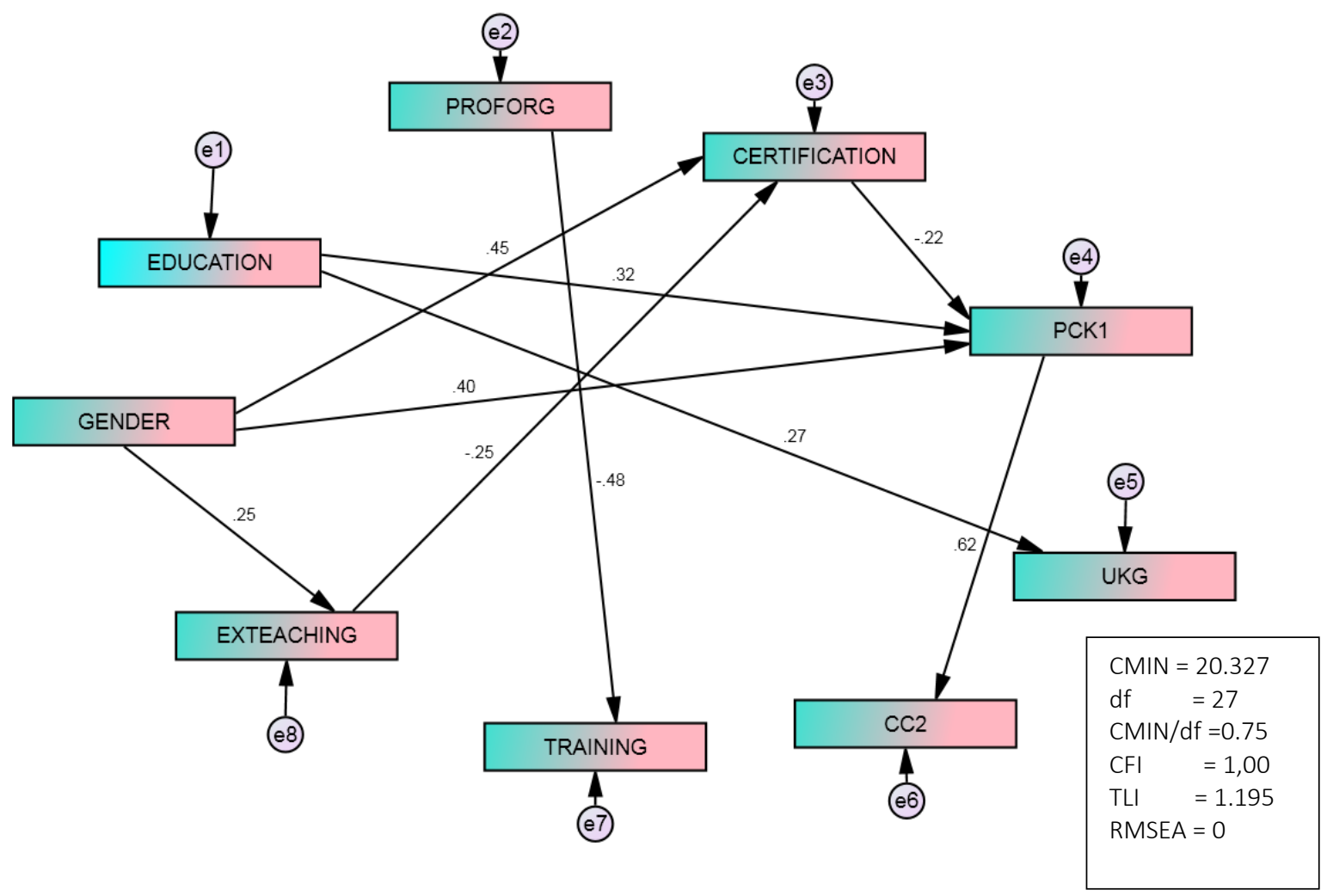

Figure 2. Final Model of Teacher Competencies Test $(n=61)$

\section{Information Teacher Competencies Test}

Based on the figure 2 the final model of teacher competencies test had been produced three outcomes variable namely UKG, CC2 and TRAINING. On the first outcome, UKG, there was one variable are found to have direct effect on it. The variable was education $(\beta=0.27)$. The positive path coefficient of EDUCATION indicates that there are significant differences between teacher who graduated from Bachelor and Master Degree on their teacher competencies test. On the words, the more likely the teacher got an education level, the higher of the teacher competencies test that they will achieve. On the second outcome namely Curriculum change (CC2) found that there was no direct variable but indirect effects on it. The indirect effects are resulted by these three variables namely Gender $(\beta=0.06)$, Certification $(\beta=0.136)$, and PCK1 $(\beta=0.248)$.The path coefficient was positive which indicates that the more teacher had been certified, the broader their pedagogical and curriculum knowledge that they have particularly on male teacher rather than the female teacher. However, the broader of teacher's pedagogical and curriculum knowledge does not guarantee the effectiveness of teacher performance as it is paralled with the previous reserach conducted by Kusumawardhani(2017) who stated that there is no strong evidence 
of the effectiveness of certified teachers on teacher performance. In addition, this finding revealed the fact that even male teacher

gained more on pedagogical and curriculum knowledege, however, the results shows that there is a slight effect on gender to teacher's knowledge $(\beta=0.06)$. It is in line with Shullman(1990) and Marks (1991) who stated that there was no any differences between male and female teachers.

Lastly, on the third outcome variable, Professional Organization had directly an effect to Training of curriculum $(\beta=0.48)$. It indicates that the more teacher active on teacher professional organization, the more likely got a chance to join the training to develop their self on curriculum and pedagogical knowledge also. It is undergone as teacher would feel the same ambiance which drive them to leverage teacher's conceptions about teaching and a joining the organization would trigger to construct new continuing professional development programs among teachers (Grangeat,M \& Gray,P,.2007).

In short, the final model of teacher competencies reveled the fact that UKG is affected directly by education background of the teacher. Another interesting finding is that the certification status does not influence more to the teachers in acquiring of the updating knowledge of curriculum change. The updating knowledge of curriculum change (CC2) shows the bigger effect size on gender's influence instead of the certification status. Therefore, it can be summed up that the updating of teacher's knowledge depends on the willingness of each individual to join the professional organization (Grangeat,M \& Gray,P,.2007) instead of the status of certification it self whereas the certification status does not have a strong evidence to reveal the real teacher performance (Kusumawardhani,2017).

\section{Conclussion}

Teacher Competencies Test (UKG) had been done by many teachers across Indonesia provinces also include the West Java Province. The test was held as a way in mapping the teacher performance level. However, many factors influenced that test not only the education and the experience in teaching but also the involvement on teacher professional organization and training also their understanding on pedagogical and curriculum knowledge. In fact, based on the calculation by using AMOS software to run Structural Equation Modelling (SEM) yielded that only one variable has a direct effect on Teacher Competencies Test (UKG) namely Education whereas the level of education background quite influence the teacher competencies test. Meanwhile, other variables have not been identified to really influence to teacher competencies test. However, it is suggested that the teacher should be allowed to have a chance to continue their study to take a higher degree in order to leverage their competencies and performance level.

\section{Reference}

Aisyah, I., Yuliasri, I., \& Warsono, W. (2018). The Professional and Pedagogic Competences of English Teachers With Different UKG (Teaching Competence Test) Achievement Levels. English Education Journal, 9(1), 74-83. https://doi.org/10.15294/eej.v9i1.27643

DeMatthews, D. (2015). Getting Teacher Evaluation Right: What Principals Need to Know. The Educational Forum, 79: 81-89, 2015.

Division of Statistics+Scientific Computation. (2012). Structural Equation Modeling Using AMOS (An Introduction). Austin : The University of Texas.

J.H. Sandholtz, S.P. Scribner. (2006). The paradox of administrative control in fostering teacher professional development. Teaching and Teacher Education, 22 (2006), pp. 1104-1117.

Hu L-T, Bentler PM. Cutoff. (1999). criteria for fit indices in covariance structure analysis: conventional criteria versus new alternatives. Struct Equ Model 1999;6: 1-55.

Hox, J.J., Bechger, T.M. (1999). An Introduction to Structural Equation Modelling. Family Science Review, 11, 354-373. [

Kline RB. (2005). Principles and Practices of Structural Equation Modeling. 2nd ed. New York, NY: the Guilford Press; p. 105. 
Kusumawardhani,P.N. (2017) .Does teacher certification program lead to better quality teachers? Evidence from Indonesia, Education Economic.s, 25:6, 590- 618, DOI: 10.1080/09645292.2017. 1329405.

L.E. Frase.(2001). Constructive feedback on teaching is missing. Education, 113 (2001), pp. 176-181.

$\mathrm{z}$

Little RJA, Rubin DB. (2002). Statistical Analysis with Missing Data. 2nd ed. New York, NY: Wiley.

MacCallum RC, Browne MW, Sugawara HM. (1996). Power analysis and determination of sample size for covariance structure modeling. Psychol Methods Page:130-149.

Marks, R. (1991). When should teachers learn Pedagogical content knowledge. Paper presented at Reviews the AERA annual meeting, 1991. California.

Mustafa, M.N., (2013). Professional Competency Differences among High School Teachers in Indonesia; International Education Studies Journal Vol.6, No.9, E-ISSN 1913-9039. DOI: 10.5539/ies.v6n9p83.

Michel Grangeat \& Peter Gray.(2007). Factors influencing teachers' professional competence development, Journal of Vocational Education \& $\quad$ Training, 59:4, 485501, DOI: $10.1080 / 13636820701650943$.

OECD. (2005). Teachers Matter: Attracting, Developing and Retaining Effective Teachers, OECD, Paris.

OECD. (2009). Creating Effective Teaching and Learning Environments: First Results from TALIS, OECD, Paris. $2009 \mathrm{~b}$

Schreiber,James B.(2008). Core reporting practices in structural equation modeling. Science Direct Research in Social and Administrative Pharmacy, 4 (2008) 83-97.

Shullman, L. S. (1990). Knowledge and teaching: Foundations of Reviews the new reform. Harvard educational review, 57(1), 1-22

Undang Undang Republik Indonesia Nomor 14 Tahun 2005 Tentang Guru dan Dosen

Yu C-Y. (2002). Evaluation of model fit indices for latent variable models with categorical and continuous outcomes. MPlus software Web site. Available from: http://www.statmodel.com; 2002. Accessed 05.01.05.

Zulfah, dan Nurjannah. (2016) .Uji Kompetensi Guru. Yogyakarta : Bright Publisher.

Widiati,U. and Hayati, Nur . (2015). Teacher Professional Education in Indonesia and ASEAN 2015: Lessons Learned From English Language Teacher Education Programs . Camtesol \& Leia:Phnom Pehn. 